\title{
Experiences and problems in the management of ascites with the Rhodiascit machine
}

\author{
H. THALER \\ M.D. \\ G. Fous \\ M.D.
}

The 4th Medical Department of the Wilhelminenspital, A-1171 Vienna, Austria

\section{Summary}

The ascites reinfusion technique is an excellent therapeutic aid to patients with cirrhosis who are otherwise in good general condition.

The loss of weight often exceeds the amount of filtrate considerably.

The ratio between filtrate and concentrate may be increased by applying a filtration pressure of between 140 and $180 \mathrm{mmHg}$. This modification could result in shortening the procedure, if the machine were fitted with wider tubes and a more efficient pump.

The treatment in three of our cases was unsuccessful.

THERE is no doubt that through the reinfusion treatment the stay in hospital of cirrhotic patients with ascites is considerably shortened. Table 1 shows the data of our last ten patients. The first was the most remarkable case. A 33-year-old male, an alcoholic from the age of 5 , consuming 51 of wine a day when admitted. He lost $22 \mathrm{~kg}$ during a 40-hr treatment which he tolerated very well. He stopped drinking and after 2 years his fluid balance is easily controlled by intermittent oral diuretic therapy.

It is difficult to explain that the actual loss of weight may exceed twice or even three times the amount of filtrate, but this phenomenon is a fact (Table 1, case 1 and 4). Diuresis cannot altogether account for this since it is usually slight during treat- ment. Other factors are perspiration as well as the reduced intake of fluid and food during therapy.

In some cases (Table 1, case 5, 7 and 8) the ratio between filtrate and concentrate is about $4: 1$. This was achieved by a slight modification of the recommended procedure (Table 2). For filtration we used a pressure between 140 and $180 \mathrm{mmHg}$. Owing to the

TABLE 2.

\begin{tabular}{lcc}
\hline & $\begin{array}{c}\text { Recommended } \\
\text { procedure }\end{array}$ & $\begin{array}{c}\text { Modified } \\
\text { procedure }\end{array}$ \\
\hline Filtration pressure $(\mathrm{mmHg})$ & $100-150$ & $140-180$ \\
Reinfusion rate $(\mathrm{ml} / \mathrm{hr})$ & $300-400$ & $100-200$ \\
$\begin{array}{l}\text { Drops/min } \\
\text { Filtration : reinfusion volume } \\
\text { ratio }\end{array}$ & $60-80$ & $20-40$ \\
\hline
\end{tabular}

higher concentration of the re-infiltrate, the number of drops per minute was only $20-40$, which means a reinfusion of $100-200 \mathrm{ml} / \mathrm{hr}$. A ratio of $2: 1$ is recommended by Rhône-Poulenc because of the fear that higher concentrations could cause an obstruction of the filter. However, this was not the case in any of our reinfusions using this modified procedure.

We used a ratio of $2: 1$, or even lower in cases of long standing ascites, because of the higher protein levels of fluid (Table 1 , case $1,2,3,4,6,9,10$ ).

Using higher filtration-pressure the capacity of the

TABLE 1. Personal and technical data of the last ten patients treated with the Rhodiascit machine

\begin{tabular}{rcccccc}
\hline $\begin{array}{c}\text { Case } \\
\text { no. }\end{array}$ & Age and sex & $\begin{array}{c}\text { Total } \\
\text { drainage } \\
(\mathrm{ml})\end{array}$ & $\begin{array}{c}\text { Filtrate } \\
\text { volume } \\
(\mathrm{ml})\end{array}$ & $\begin{array}{c}\text { Concentrate } \\
\text { volume } \\
(\mathrm{ml})\end{array}$ & $\begin{array}{c}\text { Weight-loss } \\
(\mathrm{kg})\end{array}$ & $\begin{array}{c}\text { Duration of } \\
\text { reinfusion } \\
(\mathrm{hr})\end{array}$ \\
\hline 1 & $33 \mathrm{M}$ & 15,160 & 8760 & 6400 & 22 & 40 \\
2 & $66 \mathrm{M}$ & 10,100 & 6200 & 3900 & 9 & 12 \\
3 & $67 \mathrm{~F}$ & 9900 & 6000 & 3900 & 11 & 13 \\
4 & $71 \mathrm{~F}$ & 9100 & 6450 & 2650 & 19 & 26 \\
5 & $66 \mathrm{M}$ & 8450 & 6600 & 1850 & 10 & 10 \\
6 & $69 \mathrm{M}$ & 8290 & 5380 & 2910 & 9 & 10 \\
7 & $62 \mathrm{M}$ & 7000 & 5400 & 1600 & 7 & 8 \\
8 & $50 \mathrm{M}$ & 5630 & 4800 & 830 & 6 & 7 \\
9 & $52 \mathrm{M}$ & 4625 & 2525 & 2100 & 3 & 4 \\
10 & $58 \mathrm{M}$ & 2535 & 1300 & 1235 & 2 & \\
\hline
\end{tabular}


machine could be increased and the duration of treatment shortened by approximately $25 \%$. The pre-condition for such an improvement would be wider connecting tubes and a pump working at a higher speed than $30 \mathrm{rev} / \mathrm{min}$.

There is a tendency in the first wave of enthusiasm to emphasize success and to overlook weaknesses. However, the sooner the exact indication is recognized, the better. Unfortunately in the following three patients we had no success.

A 71-year-old woman was transferred from a hospital to our department for reinfusion treatment. The diagnosis was cardiac failure due to arteriosclerotic heart disease with intractable ascites and oedema. During ascites reinfusion she suddenly became irreversibly shocked. Autopsy revealed that the heart disease was complicated by an ovarian cancer with carcinomatosis of the peritoneum.

A 66-year-old alcoholic with cirrhosis suffered from jaundice and gross ascites causing unbearable pain through abdominal tension. The thromboplastin time (Quick) was only $30 \%$. Instead of tapping, we decided to try reinfusion after a transfusion of fresh blood and clotting concentrates. During treatment a bleeding into the abdominal wall and cavity occurred. The patient died 2 days later in hepatic coma.

The third patient was a 66-year-old Hungarian who paid a short visit to Vienna. He suffered from post-hepatitic cirrhosis (Table 1, case 2). After treatment lasting $12 \mathrm{hr}$ he felt completely well and insisted on being discharged. A week later we were informed of his death, the symptoms pointing to an electrolyte coma due to uncontrolled diuretic therapy.

According to our experience we would recommend the use of the Rhodiascit machine only on cirrhotic patients in otherwise good condition with sufficiently functioning liver parenchyma. The treatment should be applied only if adequate after-care is assured. It is established that reinfusion therapy is not indicated in cases of carcinomatous ascites. Since we have followed this course we have had no further complications and the reinfusion technique is a positive extension of our therapeutic potential. 